\title{
EGY diÁK HALÁla. MIT TEHET A PEDAGógus?
}

\author{
KAPÁS ZSÓFIA * -SZABÓ ÉVA ** \\ *a Szegedi Müszaki és Környezetvédelmi Középiskola és Szakképző Iskola \\ iskolapszichológusa \\ kapas.zsofia@gmail.com \\ ** a Szegedi Tudományegyetem Pszichológia Intézetének \\ egyetemi docense \\ szeva64@gmail.com
}

A magyar tanárképzés jelenleg nem készíti fel a pedagógusokat arra, hogy az iskola intézményén belül miként kezelhetó egy általuk tanitott diák halála. Egy ilyen tragédia heves érzéseket vált ki, hiszen egy fiatal korban bekövetkezett haláleset minden esetben értelmetlennek tünik, ezáltal pedig nehezen feldolgozható. A serdülökorú diákok mélyen kötödnek kortársaikhoz, ezért gyászuk is intenzivebb, komplikáltabb lehet, igy gyakran segitségre van szükségük a feldolgozáshoz. Egy diák halála az öt tanitó pedagógusokat is érzékenyen érinti, személyes gyászuk pedig megnehezitheti számukra, hogy hatékony segitséget tudjanak nyújtani a diákoknak. Az iskola intézményi szinten is krízisbe kerülhet egy olyan tragikus haláleset kapcsán, mint amilyen például nemrégiben a West-Balkán szórakozóhelyen történt. A gyász folyamatának és a nagy valószínüséggel felmerülö problémáknak az időben történö megismerése sokat segithetnek a pedagógusoknak és az iskola vezetésének. Jelen tanulmány célja, hogy rámutasson a diák haláleseteket követö idöszak fontosabb pszichológiai jelenségeire és folyamataira, valamint hogy a nemzetközi szakirodalom áttekintése alapján bemutassa azokat az eljárásokat, amelyek segithetnek a krizishelyzet kezelésében és alapját képezhetik egy ilyen témájú képzésnek.

Egy iskoláskorú fiatal halála minden esetben nehezen feldolgozható tragédia, mely a szülőkön és a közvetlen családtagokon kívül az elhunyt iskolájának közösségét is mélyen érinti. Iskoláskorban, föleg a serdülö életszakaszban a kortárs kapcsolatok lényeges szerepet játszanak a diákok életében, ezért egy osztálytárs halála heves gyászreakciót válthat ki az elhunyt szociális közegéből. A gyász időszaka alatt a fiatalok folyamatos monitorozást, lelki támaszt vagy akár konkrét segítséget is igényelhetnek az érzelmi érintettség mértékétől függően. Ennek biztosítása részben az iskola és a pedagógusok feladata. A tanárok helyzetét egy ilyen megterhelö időszakban nem csak az nehezíti, hogy maguk is gyászolják elhunyt tanítványukat, hanem az is, hogy a pedagógusképzés során erre a feladatra nem készíti fel őket a képzőintézmény.

Az oktatók szakmai felkészítése ezen a téren több szempontból is indokolt lenne. Egy pedagógus életpálya során a tanárok nagy részének sajnos szembe kell 
néznie a fájdalmas érzésekkel és a kényes szituációkkal, amelyek egy általa tanított diák halálát követik. Akár egyetlen ilyen élmény is életre szóló nyomokat hagyhat, a veszteség megélésén és a helyzettel járó stresszen túl megjelenhet a vég nélküli tépelödés is, hogy vajon helyesen cselekedett-e akkor, vajon megtett-e mindent a gyászoló diákjaiért, amit lehetett. A pedagógusok mellett a diáktársakra is mély hatással van egy ilyen tragédia, egy kortárs halálára adott intenzív gyászreakció ebben az érzékeny életszakaszban az egész személyiség fejlödésére hatással lehet. Mindebből következik, hogy a gyászoló fiatalokat monitorozó pedagógusokra óriási felelősség hárul, amely a saját gyász megélésén túl további érzelmi terhet ró a tanárokra. Különösen kritikus lehet egy diákhalált követő krízis azokban az iskolákban, ahol nem áll rendelkezésre iskolapszichológusi segítség, és sajnos a hazai intézmények többsége ilyen (Mezö, Mezö és Józsa, 2006). Ha az iskola közössége ebben a helyzetben nem müködik együtt, a krízis intézményi szinten is komoly fennakadásokat eredményezhet a mindennapokban, akadályozva ezzel az oktatás menetét, illetve az iskolai közösség tagjainak személyes gyászfolyamatának komplikációmentes lezajlását. Mindezen okok erősen indokolják a gyászkezelés témakörének a tanárképzés alapstúdiumai közé való bekerülését, valamint az olyan továbbképzések kidolgozását, amelyek a pályán lévő pedagógusokat segíthetik abban, hogy egy ilyen tragikus szituáció ne érje őket felkészületlenül. A pedagógusokra nehezedő stressz jelentős mértékủ csökkenésén kívül mindez elösegíthet egy tudatosabb és szervezettebb intézményi szintủ gyászkezelést. Ennek következtében nő az iskolai közösség megtartó ereje, illetve jelentősen csökkenthetővé válnak a komplikált gyász kialakulásának rizikófaktorai. A jól szervezett összefogás gyorsítja az intézményi szintủ krízis lefolyását, ezenkívül jó hatással van az egyéni gyászfolyamatok alakulására is (Yule és Gold, 1993).

Tanulmányunkban áttekintjük a gyászfolyamat föbb jellemzőit, összefoglaljuk a folyamat alapjait, illetve felsorakoztatjuk a hatékony kríziskezelési eszközöket és lehetöségeket. Igyekszünk tömören összefoglalni azokat a tényeket és föbb teendöket, melyek ismerete nagy segítség lehet minden pedagógusnak.

\section{A gyász folyamatának jellemzői}

A gyász a veszteségélmény feldolgozásának folyamata. Míg az ilyenkor megtapasztalt érzések és gondolatok legtöbbünknél hasonló jellegüek, az ezekre adott emocionális és viselkedésbeli reakciók sokfélék lehetnek. Ezért óvatosan kell bánni a „normál gyászreakció” kifejezéssel. Ez a kategória a viselkedésminták széles skáláját öleli fel, vékony határvonal választja el egymástól a patológiás gyászfolyamatot és az egyéni különbségekből fakadó, szélsőségesnek tünő reakciókat. Fontos, hogy egy diák halálát követően a pedagógus tisztában legyen azzal, hogy mi is zajlik le benne és a gyászoló diákokban, hiszen csak így lesz képes effektíven kezelni a felmerülö érzéseket és viselkedésmintákat, felismerni a patológiás gyász jeleit. 
Az alábbiakban röviden áttekintjük a gyász folyamatát és a hozzá kapcsolódó fogalmakat.

\section{A gyászfolyamat lefolyása, komplikációi és kulturális vonatkozásai}

A gyásznak funkcionális szempontból négy fó célja van: elfogadni, hogy a veszteség végleges, megélni a veszteséggel kapcsolatos érzéseket, igazodni egy megváltozott élethez - új értékeket, új kapcsolatokat és új célokat kialakítani egy veszteség utáni világban -, valamint átalakítani és újraszervezni a kötődést az elvesztett személlyel (Jeffreys, 2005). Mindamellett, hogy a korábban említett egyéni különbségek fennállnak, a gyász folyamata a legtöbb ember esetében meghatározott szakaszokra osztható (Pilling, 2003).

Az első szakasz általában a sokk. Ez a tragikus hírrel való szembesülést követö azonnali reakció. Gyakran jár érzelmi bénultsággal, zavarodottsággal, esetenként váratlan dührohamok, érzelmi kitörések is megjelenhetnek. Ezt követi az ún. kontrollált szakasz. Ilyenkor a halálesettel kapcsolatos tevékenységek, rituálék szervezése, az ezeken való részvétel foglalja le a gyászolót. Ebben az időszakban felléphet derealizáció (a valóság elutasítása), deperszonalizáció (a gyászoló úgy szemléli az eseményeket, mintha azok nem is vele történnének), vagy jellemezheti egyfajta tompultság. Ez a szakasz általában a temetésig tart. Ezt követi a gyász folyamatának legnehezebb időszaka, a tudatosulás. A hivatalos elválás (temetés) után a gyászolónak vissza kell térnie az elhunyt nélküli világba és a hétköznapokban kell szembesülnie a keletkezett hiánnyal. Ambivalens és heves érzelmek jellemzik ezt a szakaszt, megjelenhet bủntudat és önvád, elöfordulhat, hogy romlik a teljesítmény, de felléphetnek fizikai tünetek, illetve jelentkezhetnek az elhunyttal kapcsolatos érzékletek, hallucinációk is. Az ambivalens érzésekböl fakadóan a gyászoló egyszer keresi, máskor elutasítja a segítséget, amelyet a baráti és/vagy rokoni kapcsolatok jelentenek. Ez az inkoherens magtartás megterheli a gyászoló szociális közegét, ami szélsőséges esetben a gyászoló barátainak eltávolodásával is járhat.

A tudatosulást követóen, néhány hónap elteltével, éles átmenet nélkül kezdődik el az átdolgozás időszaka. Ebben a fázisban a kontrollálhatatlan, tolakodó emlékek felbukkanását lassan felváltja a tudatos emlékezés. Egyre több szép emlék kerül felszínre, a társaságkerülő magatartás oldódik, a racionális elfogadás nő. Az évfordulók, ünnepek gyakran visszaesést eredményeznek a gyászfolyamatban, különösen az első év folyamán, ilyenkor újra elötörhetnek a kezdeti heves érzelmek. Végül az adaptáció szakasza következik, amikor a gyászoló visszaszerzi érzelmi egyensúlyi állapotát, képes újra büntudat nélkül örülni, új kapcsolatokat kialakítani, teljesítménye visszaáll az eredeti szintre. Fontos kiemelni, hogy a gyász lezárása nem az elhunyt elfelejtését jelenti, csupán annyit, hogy a gyászoló új helyet talált számára az életében. 
A fent leírt szakaszok a váratlanul bekövetkezett halálesetek utáni időszakot írják le. Ha a halálesetet hosszú betegség előzi meg, akkor a gyászfolyamat már korábban elkezdődik, ezt a speciális szakaszt nevezzük megelelözö gyásznak. Ilyenkor a gyászoló mintegy „felkészül” a veszteségre, ez pedig megkönnyítheti a majdani gyász lefolyását (Pilling, 2003).

Amennyiben a gyászfolyamat megreked vagy torzul, komplikált gyászról beszélünk. A komplikált gyászfolyamatokon belül megkülönböztetjük a krónikus, a késleltetett, a gátolt és a torzult gyászt. A krónikus gyász fö jellemzője, hogy a kezdeti heves gyászreakciók elnyúlnak, a folyamat megreked és nem lép új szintekre. Ebben az esetben a gyászoló mintegy kapaszkodik a fájdalomba, úgy érzi, ez az egyetlen fennmaradó kapocs az elhunyttal. Késleltetett gyászról akkor beszélünk, ha nincsenek látható jelei a gyásznak; általában akkor áll fenn, ha a gyászoló mások megsegítését helyezi előtérbe, vagy egyszerüen nincs lehetősége gyászolni. Hasonló tünetekkel jár a gátolt gyász is, de a háttérben ebben az esetben az érzések aktív elnyomása áll. A torzult gyászt a legnehezebb felismerni, mivel tünetei függetlenednek magától a veszteségélménytől; folyamatosan visszatérő fizikai vagy pszichés rendellenességek produkálásával jár ez az altípus, és minden esetben szakember segítségét igényli (Jeffreys, 2005).

A gyászfolyamat lezajlását nagymértékben segíthetik a hozzá kapcsolódó rituálék - temetés, halotti tor, gyászviselet -, melyek lehetőséget biztosítanak a veszteség átélésére és az ezzel kapcsolatos érzések kifejezésére. Emellett biztonságérzetet nyújtanak, egyrészt azáltal, hogy elöírják, mit és hogyan kell tenni, másrészt bevonják a gyászba a közösséget is, felhívják a figyelmet a gyászoló nehéz élethelyzetére, lehetőséget teremtenek az együttérzés kifejezésére, a társas támogatás megadására és toleráns magatartást váltanak ki. Ezen pozitív funkciók ellenére az utóbbi évtizedekben több hagyományos rituálé eltünt vagy elvesztette erejét. Az elkülönítő rítusok (pl. gyászviselet) hiányával a temetés után semmilyen jól látható jel nem utal arra, hogy a gyászfolyamat nincs lezárva, így a gyászoló megváltozott viselkedése értetlenséget, irritációt válthat ki az őt körülvevő szociális közegből, csökkentve ezzel a gyászfolyamat normál lezajlásához szükséges szociális támogatáshoz jutás esélyét (Simándi, 2003; Pilling, 2003).

\section{Életkori különbségek a gyászban}

A gyászfolyamat fiatalabb korban, a halálkoncepció végleges formájának kialakulása elött más jellegzetességeket mutat, mint a felnőtt gyászreakció. Kisgyermekkorban a gyász nem lineáris, sokszor nem manifesztálódik olyan formában, ami a felnőttek számára felismerhető lenne, ezért gyakran érzéketlennek gondolják a gyászoló gyereket. Ahogy a kor elörehaladtával a halál koncepciója fejlődik, a felnövő gyermek újra és újra átélheti a gyászfolyamatot (Jackson és Colwell, 2002). Az ilyen 
típusú korai veszteség rizikófaktora lehet többek között egy későbbi halálesetre adott komplikált gyászreakciónak is.

A serdülőkor különböző szakaszain belül eltérések figyelhetők meg a gyászreakcióban: a korai serdülökorban lévők mutathatnak gyermeki reakciókat, mint például a késleltetett, nem lineáris gyász. Nagymértékben sérülhet a biztonságos világba vetett hitük, mivel azt már megértik, hogy a halál végleges, ám ok-okozati összefüggéseit még nem látják át. Szorongóvá válhatnak, megjelenhet egy állandósult félelem attól, hogy ők vagy szeretteik egyik pillanatról a másikra meghalhatnak. A középserdülökor időszaka a leginkább labilis érzelmi szempontból. Bár az ebben a korban lévők halálkoncepciója már majdnem egyezik a felnőtt felfogással, énfejlődésük átmeneti állapotban van, így egy nagyobb traumától összeomolhatnak. A késői serdülökorban lévők általában már felnőtt gyászreakciót mutatnak (Balk és Corr, 1996). Tendenciaszinten megjelenhetnek nemi különbségek is, amely szerint a fiúk gyakrabban reagálnak agresszióval, mindenfajta autoritás elutasításával és káros szerek használatával a gyászra, míg a lányok leginkább szociális támaszt igényelnek és lehetőséget arra, hogy kimutathassák az érzéseiket (Raphael, 1983).

Egy haláleset által kiváltott serdülőkori krízis a gyászfolyamat komplikációmentes lefolyásától és a megfelelő segítségnyújtástól függően akár a szelf fejlődésének felgyorsulását is eredményezheti, pozitív változásokat előidézve a fiatal értékrendjének alakulásában. Többek között fontosabbá válhat az élet élvezete, a szerettekre való odafigyelés, mélyülhet az empátiás készség, emellett fejlődhetnek a copingstratégiák, nőhet az emocionális erő és jobb problémamegoldó képességekre tehet szert a serdülö (Oltjenbruns, 1996).

\section{Gyászreakciók az iskolában: tanítványt/diáktársat gyászolva}

A fiatalkorban bekövetkezett halál minden esetben értelmetlennek tünik, rendkívül nehéz a halál tényének elfogadása, mivel a gyermek- és a serdülőkor az élet azon szakasza, amelyet leginkább az egészség, a folyamatos fejlődés és a fizikai dinamizmus jellemez (Balk, Zaengle és Corr, 2011). Ezért már pusztán az elhunyt fiatal kora is kiváltó oka lehet a komplikált gyászfolyamat fellépésének (Pilling, 2003). Iskoláskorban a szociális háló kitágul, a családon kívüli kötődések elmélyülnek, így egy diák halála a családtagokon kívül az iskolai közösséget is érinti. A gyászfolyamatban nemcsak a diáktársak, de a pedagógusok is érintettek, több személy együttes gyászreakciója pedig felboríthatja a szociális viszonyokat, megnehezítheti az együttmúködést a mindennapokban.

\section{Amikor pedagógus gyászol diákot}

Egy fiatalkorú értelmetlen halála érzelmileg akkor is megterhelő egy felnőtt számára, ha nem is ismerte személyesen az elhunytat. Egy ismert, tanított diák halála, aki 
felé a pedagógus felelösségtudattal is fordul, méginkább megviselheti a tanárt. Az oktatókra így egyszerre kétféle érzelmi teher is hárul: egyrészt fogalakozniuk kell saját gyászfolyamatukkal, másrészt segítséget kell nyújtaniuk a diákoknak ebben a kritikus helyzetben. Egy ilyen szituációban előfordulhat, hogy a pedagógus saját gyásza elé helyezi az elhunyt kortársainak igényeit, ezáltal viszont saját gyászfolyamata elakadhat, és így nagy valószínüséggel nem lesz képes valós támaszt nyújtani a diákoknak sem (Lines, 2006). Ennek ellentéte is megeshet: van, hogy a tanár gyászreakciója olyan erőteljes, hogy nem marad ereje támogatóan fordulni a diákok felé, ez pedig heves büntudatot válthat ki a pedagógusból (Oltjenbruns, 1996). Mindkét eset elkerülését elősegíti, ha a pedagógusnak van lehetősége felkészülni ezekre a helyzetekre. A leghatékonyabb módja ennek a felkészülésnek, ha a pedagógus megismerkedik a gyász folyamatával, jellemzőivel, és ezáltal képessé válik könynyebben kezelni saját és diákjai érzéseit, reakcióit is.

\section{Amikor serdülő gyászol kortársat}

A serdülőkori gyászreakcióknak az életkori sajátosságok és a még formálódóban lévő halálkoncepció jellegzetességei adnak speciális keretet. A továbbiakban rámutatunk azokra az életkori tényezőkre, amelyeket egy pedagógusnak érdemes figyelembe vennie egy gyászidőszakban, mivel rizikófaktorok lehetnek a krízis elmélyülésében.

\section{A kortárskapcsolatok felértékelődése}

Serdülökorban a kortárskapcsolatok jelentősége megnö, így egy osztálytárs halálakor fontos kötődés szakadhat meg, ami mély és intenzív gyászt válthat ki. A gyászoló fiatalt körülvevő felnőttek szemében ez a reakció indokolatlanul erősnek tünhet, hiszen nem családtag hunyt el. A serdülő gyászát ilyenkor jogtalan gyásznak minősíthetik, amelyre a fájdalom bagatellizálásával, a megélt érzések megkérdőjelezésével reagálhatnak. Ebben az esetben fennáll a veszélye annak, hogy a gyászoló fiatal nem jut hozzá a szükséges szociális támogatáshoz, ez pedig lelassíthatja, megnehezítheti a gyászfolyamat lezajlását (Oltjenbruns, 1996).

A serdülő gyászreakcióját nemcsak az elhunythoz való kötődés intenzitása befolyásolja, hanem a szintén gyászoló kortárs környezet is. Ebben az életszakaszban a legtöbb fiatal úgy érzi, hogy minden kortársa őt figyeli, és minden megnyilvánulását értékelik. A csoporthoz tartozás erős vágya motiválja a fiatalt, hogy igazodjon ennek a képzeletbeli közönségnek az elvárásaihoz, így viselkedését a többség reakciójához igazítja. Ennek következtében egy sokak által gyászolt haláleset intenzív gyászreakciót válthat ki olyan serdülőkből is, akik nem álltak közel az elhunythoz, illetve ennek inverze is bekövetkezhet, azaz az elhunythoz közel álló fiatal igyekezni fog legátolni erős érzelmeit, ha kortárs környezetét látszólag nem viseli meg annyira a haláleset (Oltjenbruns, 1996). 
Az egyediség-egyformaság paradoxon szerepe a gyászreakcióban

A serdülő életszakaszban a fiatal különlegesnek, egyedinek érzi magát, ebből fakadóan hajlamos felmentést adni magának a másokra vonatkozó törvények alól: „,mindenkivel megtörténhet, de velem nem". Ez a fajta személyes mitosz azonban törékeny, és egy hasonló korú fiatal halála alapjaiban rengetheti meg, hiszen szembesülnie kell a gondolattal, hogy ha egy vele egykorú meghalhatott, akkor ez vele is megtörténhet (Balk és Corr, 1996). A személyes mítosz összeroppanása erős gyászreakciót indukálhat egy serdülöben akkor is, ha csak alig vagy egyáltalán nem is ismerte az elhunytat. Ezekben az esetekben előfordulhat, hogy a gyászoló fiatal magához hasonlatosnak kezdi képzelni az elhunytat, emiatt pedig mély empátiát kezd érezni vele kapcsolatban. A felnőttek az így felerősödő érzelmeket szintén a korábban már említett jogtalan gyász kategóriába sorolhatják (Balk és Corr, 1996; Oltjenbruns, 1996).

\section{A „túlélők”, mint csoport}

Egy serdülő halála hatással van életben maradt barátainak kapcsolataira is, ezen keresztül pedig befolyással bír a tágabb kortárs csoportra, mint amilyen például az osztályközösség. A gyász lefolyásában megjelenő egyéni különbségek kommunikációs nehézségekhez vezethetnek az osztálytársak, barátok között. Például egy befelé forduló, diszkréten gyászoló fiatal zavarónak találja a halálesetröl történő beszélgetést, míg sokaknak éppen a nyílt kommunikáció segít. Egy ilyen ambivalens érzésekkel terhelt csoportban csökkenhet az észlelt közelség élménye és kényelmetlenné válhat az együttlét. Ilyen esetekben a barátságokon belül bekövetkező negatív változások generálják a másodlagos veszteségélményt, amely plusz feszültséget ad az alapvetően is fájdalmas érzésekhez, ezáltal tovább nehezíti az egyéni gyászfolyamat lefolyását. Amennyiben a kapcsolatok bizonyos idő elteltével sem állnak helyre, a korábbi barátságok felbomolhatnak, beindítva ezzel az ún. járulékos gyász folyamatát, mely egy újabb barát és/vagy a korábbi szociális háló elvesztésére adott érzelmi reakció (Oltjenbruns, 1996). Szélsőséges esetben megnőhet az izoláció veszélye, amely negatív hatással van a fiatal személyiségfejlődésére (Lines, 2006). A barátokon kívül az elhunyt diákot nem kedvelő kortársak számára is megterhelő a gyászélmény. Jellemző ilyen esetekben a mély, bénító büntudat és önvád jelenléte, gyakori az önként vállalt izoláció. Az elhunyttal való rossz kapcsolat is rizikófaktora lehet a komplikált gyászfolyamat fellépésének (Oltjenbruns, 1996).

A társas kapcsolatokban bekövetkező esetleges változások mellett a gyász eröteljesen befolyásolhatja az iskolai teljesítményt is, mivel az érzelmi stressz miatt megváltozhatnak a tanulási szokások, a koncentráció nehézkesebbé válhat (Fleming és Balmer, 1996). Az egyébként kiváló kognitív képességekkel rendelkező diákoknál is felléphet fáradékonyság, motivációhiány, koncentrációra való képtelenség, viselkedészavar, valamint jelentkezhet erőteljesebb igény az érzelmek kifejezésére. A gyász miatt fellépő rosszabb teljesítmény idővel mérséklődik - amennyiben nem 
jelentkezik komplikáció a gyászfolyamatban - és a teljesítmény visszaáll eredeti szintjére (Davou és Widdershoven-Zervakis, 2004).

\section{Az iskola közössége és a gyász: a krízis intézményi hatásai}

Egy diák halálát követően a különbözö korosztálybéli gyászreakciók egyidejü jelenléte krízisbe sodorhatja az iskola közösségét. A diákok egyéni gyásza, a csoportok valamint az osztályok szintjén megnyilvánuló jelenségek összeadódhatnak, felerősíthetik egymást. A korábban bemutatott hatásokon és következményeken túl megnövekedhet a hiányzási arány, felmerülhetnek különböző egészségkárosító viselkedések, mint a kábítószer-, gyógyszer- vagy alkoholfogyasztás, a diákok agresszívvá válhatnak egymással vagy akár a tanárokkal szemben is. Jelentkezhet tömeges motivációhiány és apátia is (Stevenson és Stevenson, 1996). Ezek a jelenségek önmagukban is jelentős problémát okozhatnak a pedagógusoknak, halmozott előfordulásuk kezelése pedig könnyen meghaladhatja a szintén gyászoló tanárok erejét. Fontos, hogy az oktatók és a diákok képesek legyenek együttmüködni a krízis kezelésében, ennek sikertelensége esetén ez az időszak mindkét felet felörölheti, gyászfolyamatuk lassulhat, elakadhat, illetve kapcsolatuk véglegesen megromolhat. Egy olyan pedagógus, aki tisztában van a serdülőkori gyász sajátosságaival, nagyobb önbizalommal és mélyebb empátiával fog a mindennapi problémák megoldására törekedni.

\section{Iskolai teendők egy diák halálát követő időszakban}

Minden haláleset egyedi. Egyedülálló az elhunyt személyisége, életkora, más-más körülmények játszanak közre, mások az elözmények, különböznek az intézmények és az érintett személyek. Ebből fakadóan nem lehet minden lépést előre megtervezni, ám egy intézményi szintü irányvonal kijelölése jelentősen megkönnyíti a krízis kezelését. Számos kiadvány létezik, amely iránymutatást nyújt az iskolának a teendőkről egy serdülő halálát követően (NASP, 1999; Yule és Gold, 1993; Thomas és Grimes, 2002). Fontos, hogy az iskola vezetősége tisztában legyen ezen teendőkkel, hiszen az események koordinálása az ö kezükben van.

Az ajánlott intézkedések segítenek az intézménynek minél gyorsabban és a lehető legkevesebb sérüléssel feldolgozni a veszteséget, de nem ígérnek „fájdalommentességet". Az egyéni gyász minden esetben nehéz és fájdalmas, az iskola abban nyújthat jelentős segítséget, hogy csökkenti a komplikált gyász kialakulásának valószínűségét, támogató közeget nyújt, és ezáltal lehetőséget biztosít a közösség tagjainak arra, hogy foglalkozhassanak veszteségük feldolgozásával. A cél a közösségen belül egymás hatékony segítése és egymás akadályozásának elkerülése. A továbbiakban a nemzetközi szakirodalom áttekintése alapján összefoglaljuk a legfontosabb javaslatokat és módszereket, amelyek segítséget nyújthatnak egy diák halálát követő krízishelyzet kezelésében. 


\section{Intézményi szintü teendők}

Egy diák halála által kiváltott intézményi szintủ trauma súlyossága prediktora lehet a később felmerülő problémáknak. Minél súlyosabb az iskolaszintü trauma, annál valószínübb a krízis elmélyülése és annál több odafigyelést igényel annak kezelése. A trauma súlyosságát az Amerikai Iskolapszichológusok Szövetsége (National Association of School Psychologists: NASP, 1999) álláspontja szerint az alábbi kérdések feltevésével lehet felmérni:

1. Ki volt az elhunyt, milyen régóta volt tagja az iskola közösségének és mennyire tudott beilleszkedni? Minél régebben volt tagja az intézménynek, annál több embert érinthet az elvesztése.

2. Milyen körülmények között történt a tragédia? Közösségi szinten is nehezebb feldolgozni az erőszakos halálnem tényét (például gyilkosság vagy öngyilkosság esetében).

3. Hol történt a haláleset? Amennyiben az iskola területén belül történt, tanácsos szakember segítségét kérni a feldolgozáshoz, az esetleges szemtanúkra pedig fokozott figyelmet fordítani. Ha iskolai baleset következtében történt, foglalkozni kell az iskolai biztonsági elöírások esetleges felülvizsgálatával és/vagy a balesetveszély lehető leggyorsabb elhárításával.

4. Az iskola közösségéből volt-e bárkinek köze a halálesethez? Amennyiben igen - akár részese volt a tragédiának, akár előidézője - hatványozódhatnak a közösségi érzelmi reakciók.

5. A haláleseten kívül történt-e más tragédia az iskolában a közelmúltban? Egy ilyen jellegü krízis felszínre hozhat korábbi tragédiák kapcsán feldolgozatlanul maradt érzéseket, és ezek súlyosbíthatják a jelenlegi problémákat.

A trauma súlyosságának felmérése segít annak megítélésében, hogy milyen intézkedéseket kell megtenni, mely intézményi szintủ krízisintervenciós módszerek alkalmazására van szükség, illetve szükséges-e külső segítő szakember bevonása a krízishelyzet kezelésébe.

A tragédia után az első és legfontosabb intézményi szintű teendő a megfelelő tájékoztatás, azaz az információk pontosítása és azok megfelelő módon történő kihirdetése. A halál pontos körülményeit felderítendő érdemes felvenni a kapcsolatot az elhunyt fiatal szüleivel, természetesen a lehetö legnagyobb tapintattal kezelve a helyzetet, és az iskola részvétéről és támogatásáról biztosítva a gyászoló családtagokat. Fontos megtalálni az egyensúlyt a pontos tájékoztatás és az indiszkréció között. Miután a tényeket átadták a tantestületnek, azokat a lehető leghamarabb ki kell hirdetni az iskolában, megelőzve a pletykák vagy rémtörténetek elterjedését. A valótlan tények kiigazítása különösen nagy kihívást jelent az internet és a közösségi oldalak elterjedése óta, hiszen az információáramlás rendkívül rövid idő alatt bekövetkezik, így feltétlen határozottságot követel (Balk, Zaengle és Corr, 2011). 
Fontos, hogy a diákok értesítése során a közlés módja, hangneme igazodjon az érintett korosztályhoz, és legyen tekintettel az elhunythoz legközelebb álló kortársak érzéseire. A szöveg ne legyen túl hivatalos vagy személytelen. Segítséget jelenthet a diákoknak, ha szüleiket az intézmény értesíti a történtekről, például egy, a tanúlókkal hazaküldött levélen keresztül. Ebben az iskola tájékoztatást nyújthat a tragédiáról, és felhívhatja a szülők figyelmét arra, hogy gyermekük több odafigyelést igényelhet a közeljövőben (NASP, 1999; Yule és Gold, 1993; Thomas és Grimes, 2002).

Fontos figyelmet fordítani a rituálékon való részvétel elősegítésére, mivel ezeknek nagy szerepük van a gyász lefolyásában, akár egyéni, akár közösségi szinten. A serdülöknek sokat segít a veszteség feldolgozásában a szertartásokon való aktív részvétel, mint például segítés a koporsó vitelében, szavalás, éneklés egy megemlékezés keretein belül (Dyregrov, Wikander és Vigerust, 1999). A halálesetet követö első évben különösen fontos odafigyelni arra, hogy az elhunyt nélkül eltöltött ünnepnapok és évfordulók megterhelőek a gyászolók számára; az ilyen alkalmak újra előidézik a korai, heves érzelmeket, ideiglenes visszaesést eredményezve a gyászfolyamatban. Érdemes előre felkészülni erre, és az intézményi szintü ünneplés megszokott forgatókönyvébe beiktatni egy olyan szakaszt, ahol a közösség megemlékezik az elhunytról - egy perc csenddel vagy gyertyagyújtással -, ezáltal keret biztosítható a feltörő érzelmeknek (Pilling, 2003).

Amennyiben az elhunyt diák öngyilkosságot követett el, a kényes helyzet több odafigyelést igényel az iskola részéröl. Ilyenkor erősen javasolt pszichológus bevonása a krízis kezelésébe (NASP, 1999). Serdülökorban a halál gondolatával való „játszadozás” természetes, olykor egy egészséges serdülö is elgondolkodik azon, mit tennének ismerősei, ha ő meghalna. Egy valódi halálesettel való szembesülés és az emiatt fellépő heves érzelmek felerősíthetik ezeket a gondolatokat, ezért az Amerikai Szuicidológiai Szövetség (American Association of Suicidology: AAS) elsődleges javaslata az iskolák számára, hogy egy ilyen helyzetben kerüljék az elhunyt idealizálását, „mártírrá avatását”. A túlzott önvád a környezet részéről vagy az utólagosan túláradó szeretet az elhunyt felé bátorítólag hathat a halál gondolatával egyébként is fogalakozó fiatalokra. Ezekben az esetekben is fontos megemlékezni a veszteségről, lehetőséget kell teremteni az elhunyttól való elbúcsúzásra, de mindezt szükebb, visszafogottabb keretek között. Fontos magáról az öngyilkosság tényéről is beszélgetni a diákokkal, fel kell hívni a figyelmet arra, hogy senki nem hibáztatható az eset kapcsán. A tragédia az elhunyt személy saját döntésének következménye volt, a problémák kezelésének egy olyan módja, amely visszafordíthatatlan, és nem vezet igazi megoldáshoz. Ilyen esetekben is szükséges a pontos tájékoztatás és a szülőkkel való kapcsolatfelvétel, ezen kívül kiemelten fontos a diákok és a tantestület tagjainak gyászfolyamatát fokozottan és hosszabb távon figyelemmel követni. Egy öngyilkosságot követően nagyobb a valószínüsége a komplikált gyász fellépésének, mivel ez a halálnem minden esetben fokozott büntudatot és önvádat vált ki a gyászolókból. Hasznos lehet ilyen esetekben egy előadás vagy be- 
szélgetés a depresszió tüneteiről, az öngyilkosság lehetséges előjeleiről, a diákok bíztatása a fokozott odafigyelésre, szerepvállalásra és a közbeavatkozásra. Fontos minden fórumon hangsúlyozni, hogy a diáktársak közül senki nem felelös a történtekért, illetve tudatosítani bennük, hogy mindig van választási lehetőségük, mindig elérhető a segítség (Thomas és Grimes, 2002).

Hasonlóan fokozott figyelmet és körültekintést igényel, ha a diák kortárs eröszakos halál következtében hunyt el. Ezekben az esetekben az erős szorongás állandó jelenléte mellett előfordulhat, hogy a gyászoló nem képes szabadulni az elhunyt életének utolsó pillanataitól, gyakoriak a kontrollálhatatlanul betörő vizuális képzetek a halálesetről. Ilyenkor hangsúlyozottan tanácsos szakember segítségét kérni a gyászfolyamat komplikációmentes lezajlásának elősegítéséhez (Cohen és Mannarino, 2011).

Az intézményi szintü krízisintervenció során a legnagyobb segítséget az iskolapszichológus nyújthatja (Porkolábné és Szitó, 2003). Amennyiben az intézményben nem dolgozik ilyen szakember, érdemes külső pszichológus segítő bevonásán elgondolkodni. A halálesettel és a gyásszal kapcsolatos kétszemélyes és csoportos beszélgetések a közösség összes tagjának bizonyítottan hasznára válnak (Yule és Gold, 1993). Fontos, hogy a diákokra való odafigyelés mellett a tantestület minden tagja foglalkozzon saját gyászával és érzéseivel is, mert ezek elnyomása a gyászfolyamat lassításán kívül inadekvát viselkedésformákhoz vezethet. A pedagógusok érzéseinek feldolgozásában is értékes segítséget nyújthat egy kompetens szakember (McCaffrey, 2004).

\section{Munkakörök szerinti teendök}

Az iskola igazgatójának akkor is fontos szerepe van, ha esetleg nem is tanította az elhunyt diákot. Az ő feladata az intézmény nevében reagálni a tragédiára, segíteni az iskolát a krízisintervenció megszervezésében, szem előtt tartva a közösség tagjainak személyes igényeit.

A halálesetet követően az igazgató elsődleges teendője a szülökkel való kapcsolatfelvétel - abban az esetben is, ha a tragédia tanítási szünet idején következett be. Fontos a részvétnyilvánítás az intézmény nevében, illetve a halál körülményeire vonatkozó információk pontosítása. Amennyiben tanítási időszakban történt a tragédia, érdemes egy tanítás elötti rendkívüli tantestületi megbeszélést összehívni, átadni a tanároknak a pontos információkat, illetve ha ez nem lehetséges, a nap elején írásban eljuttatni minden pedagógusnak a haláleset pontos körülményeit, esetleg emellett az intézmény támogatásáról biztosítani őket (NASP, 1999). Az igazgató feladata egyeztetni a tanárokkal az esetleges rutinváltásról, illetve engedélyezni azt. Ilyenek lehetnek: a tanterv ideiglenes felfüggesztése, a számonkérések elnapolása, rendkívüli osztályfönöki órák engedélyezése stb. Amennyiben az iskola eltér a normál tanrendtöl, fontos odafigyelni az ahhoz való visszatérés fokozatosságára, például 
minden nappal csak kis mértékben emelni a házi feladat mennyiségét - erről is érdemes az igazgatónak egyeztetni a tanárokkal (Dyregov, 2004).

A vezető feladata továbbá az intervenciós tevékenységek megszervezése és azok monitorozása is. Amennyiben ezekhez szükség van szakember segítségére, az iskola vezetésének kell felvennie a kapcsolatot a különböző segítő szervekkel. A rituálék koordinálása, például gyertyagyújtás az iskolában, a temetésen történő intézményi részvétel, illetve a hosszú távú megemlékezési szertartások megszervezése is az igazgató felelőssége (NASP, 1999; Thomas és Grimes, 2002). A tantestület gyászoló tagjainak sokat segíthet a tragédia feldolgozásában, ha az iskola vezetősége érezteti velük támogatását, illetve ha biztosítja számukra annak lehetőségét, hogy gyászukkal az intézményen belül is tudjanak foglalkozni (például szakember által vezetett csoportos konzultációk keretében). Az intézményvezető teremtheti meg a lehetőségét egy szakember által koordinált előadásnak is a normál gyászfolyamat mibenlétéröl; egy ilyen alkalom segít a tanároknak felismerni, hogy amin keresztülmennek, amit megtapasztalnak és amit éreznek mind egy normális folyamat részei. Emellett felvilágosítást kaphatnak arról, hogy a diákok részéről milyen reakciók és viselkedésformák megjelenései várhatóak, ez pedig növelheti kompetenciájukat és önbizalmukat a szituáció kezelésének kapcsán (McCaffrey, 2004).

Az elhunyt fiatalt egykor tanító tanárnak a diákokra való odafigyelés mellett saját felelössége önmagának is figyelmet szentelni, saját gyászával foglalkozni. Amennyiben a haláleset nyáron következett be, a pedagógusnak több ideje és lehetősége van saját veszteségének feldolgozására, egy tanév közben bekövetkező tragédia esetén pedig hasznos lehet szakember segítségét kérni ehhez (NASP, 2003).

A tragédiát követő elsö, osztályszintü beszélgetésen a tanár (osztályfönök) személyes érzéseinek, gondolatainak, halállal kapcsolatos élményeinek megosztása, a pedagógus szerepből való ideiglenes kilépés pozitívan hathat a tanulókra, segíthet a bizalmi légkör kiépítésében és a csoport összefogásában (Lines, 2006). Fontos ezt a beszélgetést akkor is megtartani, ha a haláleset nyáron történt és csak hetekkel a tragédia után találkozik az osztály az oktatóval. A serdülőknek a legtöbbet a kétirányú kommunikáció segít, ahol a tanár is aktív és ők is beszélhetnek. A haláleset konkrét körülményeinek megvitatásán kívül érdemes a halál általános koncepciójáról is beszélgetni a diákokkal, esetleg filozófiai kérdéseket felvetni, természetesen odafigyelve az esetleges világnézeti és vallási különbségek tiszteletben tartására (Noppe és Noppe, 1996). Egy ilyen jellegü, segítő szándékú beszélgetés során jó, ha a csoport egésze mellett a pedagógus figyelembe veszi a csoportot alkotó egyének igényeit is. Egy osztályszintü, kétirányú beszélgetés serdülőkorban inkább a lányok érzelmi igényeire reagál, a fiúk ebben az életszakaszban nehezebben nyílnak meg, nekik többet segíthet valamilyen jellegü aktivitással - sporttal, alkotó tevékenységgel vagy a rituálék szervezésében való részvétellel - egybekötött, spontánnak tünő, kevesebb ember előtt zajló beszélgetés. Mindemellett a müvészi 
alkotótevékenységek pártolása nemtől függetlenül sokat segít a fiataloknak érzéseik kezelésében (Dyregrov, Wikander és Vigerust, 1999; Dyregrov, 2004).

Egy tanuló halálát követően megnő a valószínüsége a tanulmányi eredmények romlásának. Amennyiben egy tanár ezzel elöre tisztában van és ehhez mérten reagál a jegyek romlására és a házi feladatok elmaradására, gyorsabban helyreállhat az eredeti állapot és kevesebb feszültséggel kell megküzdenie minden érintettnek. Hasonló a helyzet a magatartási problémákkal is. Főleg a haláleset által mélyen érintett diákok esetében érdemes alternatív fegyelmezési módszereket alkalmazni, akár hosszabb távon is (McCaffrey, 2004; Dyregrov, 2004).

A csoport reakcióinak kezelésén kívül fontos figyelmet fordítani az egyéni szintủ reakciókra is. Mivel a diákokat tanító pedagógus napi kapcsolatban áll a fiatalokkal, több alkalma van a komplikált gyász vagy a depresszió jeleit felfedezni rajtuk, és ezáltal azonositani a szakember segitségére szoruló tanulókat. Az elhunythoz legközelebb állók és a labilis személyiségü diákok a leginkább veszélyeztetettek ilyen szempontból, ezért őket érdemes kiemelt figyelemmel kísérni hosszabb távon is (Hill és Foster, 1996). Öngyilkosság esetén ez hatványozottan javasolt, mivel a gyászoló kortársak körében megnőhet a depresszió kialakulásának esélye (Brent et al., 1992).

Amennyiben szakember nem hozzáférhető, az oktató dönthet úgy, hogy saját segítségét ajánlja fel a gyászoló diákoknak. A segítő beszélgetés gyakorlati haszna bizonyított (Pattison és Harris, 2006). Ebben az esetben érdemes a szülöket is értesíteni, hogy gyermekük számára nyitott a lehetőség ezt a fajta segítséget igénybe venni (McCaffrey, 2004; Pilling, 2003). Fontos azonban hangsúlyozni, hogy ilyen szituációban valódi segítséget csak olyan pedagógus képes nyújtani, aki legalább minimális szinten felkészült a gyászfolyamat különböző jeleinek felismerésére és jártas a segítö beszélgetés technikájában. Több kiadvány, könyv és segédanyag is elérhető, amely önmagában is jelentős segítséget nyújthat gyászoló fiataloknak. Előnyös lehet, ha ezeknek utánanéz az adott tanár, hogy később ajánlani tudja öket, illetve az iskola megfontolhatja hasonló jellegü irodalmak beszerzését is (Gootman, 2005; Wolfelt, 2001).

Tömören összesítve a NASP (1999) az alábbi pontokban határozta meg egy pedagógus teendőit diákhalál esetén:

- pontos információt szolgáltatni a diákoknak a haláleset körülményeiről, megelőzni és elhárítani a pletykákat;

- ha szükséges, a tantervet átmenetileg felfüggeszteni;

- tudatosítani, hogy saját viselkedése modellként szolgál a gyászoló diákok számára;

- osztályszintű beszélgetéseket folytatni, kérdésekre válaszolni a halál filozofikus vonatkozásaiban is, nem csak a konkrét eset kapcsán;

- felmérni, hogy melyik diák szorul segítségre, és hogy ő mint tanár miben tud segíteni; 
- biztosítani a gyászoló fiatalokat arról, hogy a szélsőséges érzelmek ilyenkor teljesen egészségesek (normailzálni azokat), illetve teret biztosítani ezek kifejezésére;

- a temetésen és más rituálékon való részvétel megszervezésében részt venni;

- illetve felismerni és szakemberhez irányítani a súlyos krízisben lévő diákokat.

\section{A krízis után}

A halálesetet követő rövidtávú krízisintervención kívül az iskola közösségének hasznára válhat a hosszú távú posztvenció is. Ez a krízis lezajlása utáni, az adott halálesettel kapcsolatos tevékenységeket takarja. A posztvenció által az intézmény megkönnyítheti a gyászfolyamatok lezárulását, mivel szervezett kereteken belül biztosít a lehetőséget az elhunyt emlékének ápolására, elösegítve ezzel a hozzá füződő kötődések újradefiniálását. Csoportos szinten a posztvenció magában foglalja az emlékek rituális ápolását (pl. a sírhely rendszeres, szervezett látogatásával, a haláleset évfordulóján gyertyagyújtással), rendszeres megemlékezéseket (rendezvényeken, ünnepnapokon egy perc néma csendet az elhunytnak szentelve, különösen a tragédiát követő első évben) illetve az osztály igényeinek megfelelően különböző személyes jelentőségü cselekvéseket (pl. az elhunyt padját üresen hagyni, a tablóra kitenni a fényképét). Mindehhez az igazgató, a tanárok és a diákok együttes odafigyelése és együttmüködése szükséges, ezen kívül érdemes lehet bevonni a szülöket is, akiknek szintén sokat segíthet, ha látják, elhunyt gyermekük emlékét nem csak ők őrzik (Hill és Foster, 1996).

Jó, ha az intézmény hosszútávon is együttmüködik különböző segitő szervekkel és krízisközpontokkal, hogy hónapokkal a haláleset után is tudja hová irányítani a szakemberek segítségére szoruló fiatalokat. Léteznek olyan komplikációk, melyek tünetei nem közvetlenül a haláleset utáni időszakban jelennek meg, vagy időben elnyúlnak és az intézményi krízis lezajlását követően is problémát okozhatnak - ilyen lehet például a depresszió vagy a komplikált gyász bizonyos formái (Hill és Foster, 1996).

\section{Felkészülés egy esetleges krízishelyzetre}

Egy diák halálát követő intézményi szintü krízissel megbirkózni minden alkalommal nehéz, de ennek lefolyását gyorsíthatja egy előzetesen erre a helyzetre megírt „forgatókönyv”. Ha mindenki tisztában van azzal, mi a feladata, csökken a szervezetlenség, és a közösség minden tagjának kevesebb stresszel kell megküzdenie egyéni gyásza mellett, ez pedig gyorsítja a gyászfolyamatot és csökkenti a komplikációk fellépésének valószínűségét (Yule és Gold, 1993).

A tragédiára adott hivatalos tennivalók összerendezése mellett jelentősen könynyíthet egy haláleset feldolgozásán a serdülők halálkoncepciójának eseménytől 
független fejlesztése és az ehhez kapcsolódó megküzdési stratégiák ismertetése. Az úgynevezett haláloktatás lényege, hogy felvilágosítást ad a halál és a gyász mibenlétéről, teret enged a kérdéseknek és a filozófiai gondolatok rendezésének. Bár mindez hasznos lehet egy diák halálát követő időszakban is, egy konkrét tragédiától függetlenül megtartott oktatás többet segíthet egy később bekövetkező krízishelyzetben, hiszen ebben az esetben van elég idő az új stratégiák megszilárdulására. Ezeknek a beszélgetéseknek keretein belül a halál biológiai okaitól kezdve annak mitologikus felfogásán keresztül a személyes élményeken át a gyász folyamatáig minden halállal kapcsolatos dolog körüljárható.

A haláloktatás nem feltétlenül szakemberhez kötött, pedagógus is vállalkozhat a halálról történő mesélésre, az arról folytatott beszélgetésre. Ez nem gyakori jelenség, mivel a tanároknak sokszor nehéz a halálról beszélni, föleg gyerekekkel és serdülőkkel, hiszen ők még fiatalok, „tele vannak élettel”, ráadásul komplikált lehet őket megfelelő hangnemben megszólítani. Mindezen felül a nyugati társadalmak tabuként kezelik a halált, így előfordulhat, hogy maga a pedagógus sincs felkészülve egy ilyen témájú beszélgetésre (Lines, 2006). Léteznek olyan kiadványok, melyek erre a szituációra specializálódnak, és segítenek az oktatóknak korosztályhoz illő hangnemben beszélni a halálról és az ehhez kapcsolódó fogalmakról, jelenségekről (például Jackson és Colwell, 2002.).

A haláloktatás egy fajtája a vallásos felfogások átadása. Ez is megvalósítható az iskolán belül, de érdemes inkább ajánlás szintjén egy hiteles emberhez, lelkészhez vagy a vallást régóta gyakorlóhoz irányítani a serdülőket. Egy vallási közösség tagjaként a veszteség feldolgozása könnyebbnek tűnhet, mivel a rituálék és a halál vallásos magyarázatai biztonságérzetet nyújtanak és csökkentik a gyászfolyamattal járó esetleges büntudatot (Stevenson és Stevenson, 1996).

A haláleset feldolgozásával való megbirkózás, valamint a haláloktatásra való felkészítés jelenleg a tanárképzés egyik hiányzó eleme. Sok más készségfejlesztés mellett érdemes volna nagyobb szerepet szánni ennek - a társadalomban is gyakran tabuként kezelt - témának a feldolgozására. A felkészítő folyamatnak a képzésben legalább három lépésben kellene megtörténnie. Egyrészt szükséges volna olyan elméleti ismeretek átadása, amelyek rámutatnak ennek a kritikus folyamatnak a föbb jellegzetességeire, pszichodinamikai következményeire. Ha nem is önálló kurzus keretében, de lehetőleg minden hallgatónak kellene ismereteket kapnia ezen a területen. Ezt követően már szabadon választható módon és tréning alapú tanulási környezetben szükség lenne a tanárjelöltek saját halálkoncepciójának és halállal kapcsolatos élményeinek feldolgozására. A harmadik lépésben erre épülően lehetne elkezdeni a haláloktatáshoz szükséges készségek fejlesztését, ennek egyfajta gyakorlását szintén kiscsoportos, tapasztalati tanulási módszerekre épülő fogalakozás keretében. A tanárképzésen túl ennek a témának helye volna a tanártovábbképzésben is, ahol azok a pedagógusok is megismerkedhetnének a probléma kezeléséhez 
szükséges elméleti és gyakorlati ismertekkel, akiknek erre a korábbi képzésük során nem volt lehetőségük.

\section{Összegzés}

A fentiekben röviden összefoglaltuk és bemutattuk a gyász folyamatát annak életkori jellemzőivel együtt, illetve kiemeltük azokat a teendőket, amik irányt mutatnak az iskola szervezeti teendőivel kapcsolatban. Egy diák halálát követően a pedagógusokra, kiváltképp az osztályfönökökre különösen nagy érzelmi teher és felelősség hárul: saját gyászuk mellett a diákok gyászfeldolgozását is segíteniük kell. Mivel a nyugati társadalmakban a halál és a gyász egyre inkább tabunak számít, egyre kevésbé támaszkodhatunk a szokásokra és a rituálékra. A legtöbb ember nincs felkészülve arra, hogy másoknak segítséget nyújtson a gyászolásban, különösen ijesztő lehet ez a feladat egy olyan felelösségteljes munkakörben, mint amilyen a pedagógusi. A terhet növeli, hogy a tanárok tisztában vannak azzal, hogy milyen erős befolyással bír a viselkedésük, mint modell, a gyászoló diákok számára (Papadatou et al., 2002). Az elöre lefektetett teendők, akár forgatókönyvszerüen kidolgozva, pótolják a hagyományok útmutató, biztonságot adó szerepét.

Mivel ebben az életkorban a diákokat egyébként is foglalkoztatja a halál fogalma, mindenképp hasznos, ha ezeket a gondolatokat megoszthatják, megbeszélhetik egymással. Ennek keretet biztosíthathatnak olyan osztályfönöki órák, melyek során az osztályfőnök osztályával a halál, gyász témájában folytat beszélgetést. Ehhez elsősorban saját gondolatait, érzéseit szükséges átgondolnia, megfogalmaznia. Az őszinteség, az érzések nyílt kommunikációja ebben a helyzetben elengedhetetlen, hiszen ez az, ami segíti a diákok saját érzéseinek és gondolatainak normalizálását, tehát annak megértését, hogy félelmetesnek vagy furcsának tartott gondolataikkal nincsenek egyedül, és természetes, hogy adott módon éreznek. Hasznos lehet a müvészettel foglalkozó tantárgyak tantervével, az azokat oktató tanárokkal összehangolni a gyász témájának feldolgozását.

A serdülőkre jellemző halálkoncepció és gyászfolyamat megismerésével a diákok gondolatainak megértése és a velük való interakció könnyebbé válik - az érdeklödőknek magyar nyelven például Singer Magdola 2010-ben megjelent, Vigasztalódás a gyászban címü kiadványa, angolul pedig Perschy (2004) Helping Teens Work Trough Grief címü müve nyújthat értékes segítséget. A pedagógusokat nagyban segítheti az is, ha egymás közt folytatnak beszélgetést arról, hogy egy diák halálát követően hogyan éreznének, mit tennének. Gyakran megjelenik a gyász kezelésével kapcsolatos bizonytalanság, a félelem, hogy a tanár rosszul csinál valamit, még nagyobb kárt okoz a diákokban. A megbeszélés nemcsak a saját érzéseik normalizálását szolgálhatja, hanem biztonságot nyújt, ötleteket ad, illetve az esetlegesen bekövetkező krízishelyzetben a pedagógust biztosíthatja munkatársai társas és szakmai támogatásáról. 
Úgy gondoljuk, hogy a pedagógus szerepe, teendői egy ilyen krízishelyzetben alapvetően szakmai kérdésnek tekinthetők, a képzés során a pedagógusokat azonban semmilyen módon nem készítik fel egy ilyen nehéz feladatra. Ennek a felkészítésnek a része kellene hogy legyen a gyászfolyamat, különösképp annak életkori jellemzőinek bemutatása, a pedagógus, főként az osztályfönök szerepe a diákok gyászának feldolgozásában, a haláloktatás, illetve a krízishelyzetben való kommunikáció gyakorlati formában történő fejlesztése. Mindez zökkenőmentesen beilleszthető a pedagógusok jelenlegi pszichológiai képzésébe, gyakorlati haszna pedig vitathatatlan. A már pályán lévő tanárok, iskolai vezetők számára egy hasonló tantervü továbbképzés szolgálhatna a fenti „biztonsági kapaszkodókkal”, melyek egy intézményi krízis során jelentősen megkönnyítik feladataikat.

\section{Irodalom}

Balk, D. E., Corr, C. A. (1996): Adolescents, developmental tasks and encounters with death and bereavement. In: Corr, C. A. - Balk, D. E. (eds.): Handbook of adolescent death and bereavement. Springer Publishing Company, New York, 3-24.

Balk, D. E., Zaengle, D., Corr, C. A. (2011): Strengthening grief support for adolescents coping with a peer's death. School Psychology International, Vol. 32., Issue 2., 144-162.

Brent, D. A., Perper, J., Moritz, G., Allman, C., Friend, A., Schweers, J., Roth, C., Balach, L., Harrington, K. (1992): Psychiatric effects of exposure to suicide among the friends and acquaintances of adolescent suicide victims. Journal of the American Academy of Child \& Adolescent Psychiatry, Vol. 31., Issue 4., 629-639.

Cohen, J. A., Mannarino, A. (2011): Supporting children with traumatic grief: What educators need to know. School Psychology International, Vol. 32., Issue 2., 117-131.

Corr, C. A., Balk, D. E. (eds.) (1996): Handbook of adolescent death and bereavement. Springer Publishing Company, New York.

Dyregrov, A. (2004): Educational consequences of loss and trauma. Educational and Child Psychology, Vol. 21. (3), 77-84.

Dyregrov, A., Wikander, A. M. B., Vigerust, S. (1999): Sudden death of a classmate and friend - Adolescents' perception of support from their school. School Psychology International, Vol. 20. (2), 191-208.

Davou, B., Widdershoven-Zervakis, M. A. (2004): Effects of mourning on cognitive processes. Educational and Child Psychology, Vol. 21. (3), 61-76.

Fleming, S., Balmer, L. (1996): Bereavement in adolescence. In: Corr, C. A. - Balk, D. E. (eds.) Handbook of adolescent death and bereavement. Springer Publishing Company, New York, 139-154.

Gootman, M. E. (ed.) (2005): When a friend dies - A book for teens about grieving and healing. Free Spirit Publishing Inc., Minneapolis.

Hill, D. C., Foster, Y. M. (1996): Postvention with early and middle adolescents. In: Corr, C. A. - Balk, D. E. (eds.): Handbook of adolescent death and bereavement. Springer Publishing Company, New York, 250-272. 
Jackson, M., Colwell, J. (2002): A teacher's handbook of death. Jessica Kingsley Publishers Ltd., London.

Jeffreys, J. S. (2005): Helping grieving people - When tears are not enough. A handbook for care providers. Brunner-Routledge, New York.

Lines, D. (2006): Brief counselling in schools: Working with young people from 11 to 18 . Sage Publications Ltd., Thousand Oaks.

McCaffrey, T. (2004): Responding to crises in schools: A consultancy model for supporting schools in crisis. Educational and Child Psychology, Vol. 21. (3), 109-121.

Mező Ferenc, Mező Katalin, Józsa Balázs (2006): Egy országos iskolapszichológiai helyzetfelmérésre tett kísérlet tapasztalatai. Alkalmazott pszichológia, $8 \mathrm{sz}$. 124-136.

NASP (1999): Death: Dealing with crisis at school - Practical suggestions for educators. Letöltés ideje: 2012. június 10. http://nasponline.org/resources/crisis_safety/neat_poland.aspx\#

NASP (2003): Helping children cope with loss, death and grief - Tips for teachers and parents. Letöltés ideje: 2012. június 10. http://nasponline.org/resources/crisis_safety/griefwar.pdf

Noppe, L. D., Noppe, I. C. (1996): Ambiguity in adolescent understandings of death. In: Corr, C. A. - Balk, D. E. (eds.) Handbook of adolescent death and bereavement. Springer Publishing Company, New York, 25-41.

Oltjenbruns, K. A. (1996): Death of a friend during adolescence: Issues and impacts. In: Corr, C. A. - Balk, D. E. (eds.) Handbook of adolescent death and bereavement. Springer Publishing Company, New York, 196-216.

Papadatou, D., Metallinou, O., Hatzichristou, C., Pavlidi, L. (2002): Supporting the bereaved child: Teachers' perceptions and experiences in Greece. Mortality, Vol. 7., No. 3., 324-339.

Pattison, S., Harris, B. (2006): Adding value to education through improved mental health: A review of the research evidence on the effectiveness of counselling for children and young people. The Australian Educational Researcher, Vol. 33. (2), 97-121.

Perschy, M. K. (2004): Helping teens work through grief. Brunner-Routledge, New York.

Pilling János (szerk., 2003): Gyász. Medicina Könyvkiadó, Budapest.

Pilling János (2003): A gyász kulturális vonatkozásai. In: Pilling János (szerk.): Gyász. Medicina Könyvkiadó, Budapest, 19-26.

Pilling János (2003): A gyász lélektana. In: Pilling János (szerk.): Gyász. Medicina Könyvkiadó, Budapest, 27-54.

Pilling János (2003): A gyászolók segítésének lehetőségei. In: Pilling János (szerk.): Gyász. Medicina Könyvkiadó, Budapest, 55-76.

Porkolábné Balogh Katalin, Szitó Imre (2003): Az iskolapszichológia néhány alapkérdése. ELTE Eötvös Kiadó, Budapest.

Raphael, B. (1983): The anatomy of bereavement. Basic Books, New York.

Simándi Erzsébet (2003): A gyászolók jogi támogatása - Tiszteljük a halott emlékét! A kegyeletsértés mint gyászmunkát megrekesztő cselekmény. In: Pilling János (szerk.): Gyász. Medicina Könyvkiadó, Budapest, 297-300. 
Singer Magdolna (2010): Vigasztalódás a gyászban - A haláleset és a válás utáni veszteség feldolgozása. Jaffa Kiadó, Budapest.

Stevenson, R. G., Stevenson, E. P. (1996): Adolescents and education about death, dying, and bereavement. In: Corr, C. A. - Balk, D. E. (eds.) Handbook of adolescent death and bereavement. Springer Publishing Company, New York, 235-249.

Thomas, A., Grimes, J. (eds., 2002): Best practices in school psychology IV. NASP Publications, Bethesda.

Wolfelt, A. D. (2001): Healing your grieving heart - for teens. 100 practical ideas. Companion Press, Fort Collins.

Yule, W., Gold, A. (1993): Wise before the event - Coping with crises in schools. Calouste Gulbenkian Foundation, London. 